Saudi Journal of Oral and Dental Research

Abbreviated Key Title: Saudi J Oral Dent Res

ISSN 2518-1300 (Print) |ISSN 2518-1297 (Online)

Scholars Middle East Publishers, Dubai, United Arab Emirates

Journal homepage: https://saudijournals.com/sjodr

Review Article

\title{
Caries Vaccine: An Overview
}

\author{
Dr. Charvi Gupta ${ }^{*}$, Dr. Hemant Mankel
}

Assistant Professor, Mekelle University, Ethiopia

DOI: $10.36348 /$ sjodr.2020.v05i05.003

| Received: 13.05.2020 | Accepted: 20.05.2020 | Published: 23.05.2020

*Corresponding author: Dr. Charvi Gupta

\section{Abstract}

One of the most common diseases in humans is dental caries. It is an infectious disease of microbiological origin that results in localized dissolution and destruction of the calcified tissue of teeth. It is a diseased caused by multitude of factors like host, agent and environmental factors. Microbes like S. mutans, Lactobacillus acidophilus and Actinomyces viscosus are the main pathogenic species involved with initiation and progression of dental caries. Indian surveys demonstrate caries prevalence of 58\% in school children. Among the U.S. Population surveys showed $45.3 \%$ children and $93.8 \%$ of adults. A large costing of dental treatments whether prevention using remineralizing agents and treatment using restorative materials can be reduced if we could eradicate dental caries completely. Thus the ultimate objective of community health is the complete elimination of this disease. Development of dental caries vaccines is a boon for eradication of this microbiological disease.

Keywords: Dental caries, infectious disease, microbes, S.mutans, prevention, dental caries vaccines.

Copyright @ 2020: This is an open-access article distributed under the terms of the Creative Commons Attribution license which permits unrestricted use, distribution, and reproduction in any medium for non-commercial use (NonCommercial, or CC-BY-NC) provided the original author and source are credited.

\section{INTRODUCTION}

Dental caries is an infectious microbiologic disease of the teeth that results in localized dissolution and destruction of calcified tissue [1]. Developed countries has prevalence rate of dental caries as high as $90 \%$ and the rate is increasing greatly in developing countries [2]. It is a disease caused by multitude of factors like host, agent and environmental factors. Microbes like S.mutans, Lactobacillus acidophilus and Actinomyces viscosus are the main pathogenic species involved with initiation and progression of dental caries [3]. S. mutans is the main causative agent responsible for initiation of dental caries. It has varied species as Streptococcus cricetus, Streptococcus ferus, Streptococcus macacae, Streptococcus rattus, Streptococcus downey, Streptococcus mutans and Streptococcus sobrinus. S.mutans is the most prevalent species among animals and humans, and S.mutans and S. sorbinus are exclusively isolated from humans [4].

In order to replace previous methods of curing dental caries which was "to drill and fill", measures have been taken to prevent dental caries, among which one is to immunize the population against the disease through dental caries vaccine [3]. This approach to the prevention of dental caries should not be regarded as being in competition with other methods such as use of water fluoridation, topical fluorides in the form of mouth rinses, sealants, topical varnish, antimicrobial chemotherapeutics, or good dietary habits. Immunization with combination of all other techniques which have been mentioned, may contribute towards an even greater reduction of the prevalence of the disease [5]. A review of literature is presented over dental caries vaccine.

\section{VACCINES}

Vaccines are an immune-biological formulation used to produce a specific protection against a given disease. It leads to production of a protective antibody and stimulate other immune mechanisms. They are prepared from live modified, inactive or killed organisms, toxoids, cellular fractions or their combinations [6].

\section{THE IMMUNE RESPONSE \\ The Primary response}

When an antigen is administered for the first time, it has a latent period of 7-10 days after which the first line antibodies are developed which are primarily IgM type. They rise for next 2-3 days to a peak level and then it falls instantly as soon as it is developed. In conditions where antigen stimulus is sufficient, there is a surge of IgG antibodies after 7-10 days and their level also declines slowly and gradually over a period of months. Memory cells are produced by both $\mathrm{B}$ and $\mathrm{T}$ 
lymphocytes which are responsible for immunological memory after immunization [7].

\section{The secondary response (Booster)}

Secondary response is much different from primary response. There is a surge in both IgM and IgG antibodies. Collaboration is necessary between the $\mathrm{B}$ and $\mathrm{T}$ lymphocytes to have immunological memory. The IgM antibodies stays for transient time but IgG antibodies stay for longer time.

This collaboration of primary and secondary response is referred to as immunological memory and is the basis of vaccination and revaccination [7].

\section{Mechanism of Vaccine Action}

The saliva contains $1-3 \%$ of antibodies primarily of which are $\operatorname{IgA}$. But IgM and IgG are some antibodies also present in gingival crevicular fluid. There are certain cellular immunological agents like lymphocytes, macrophages and neutrophils that are also associated with immunological response.

Some of the possible ways antibodies control microbial growth are [8].

1. The salivary agglutinin may interact with bacterial surface receptors and inhibit their colonization.

2. It may also inactivate surface glucosyltransferase which would further reduce the extracellular glucans resulting in reduction in plaque formation.

3. The salivary glands produce secretory antibody $\operatorname{IgA}$ by direct immunization of gut associated lymphoid tissue (GALT). Since these antibodies has direct access to tooth surface they prevent S. mutans to adhere to the enamel surface or it may inhibit activity of glucosyltransferase (GTF) and may prevent formation of dextran.[2]

\section{Antigenic determinants of s. Mutans}

Adhesins: purified from two major microorganisms- S. mutans and S. sorbinus.

Glucosyltransferases: 3 types are available

- Water-soluble glucan synthesizing enzymes: GTF$\mathrm{S}$

- Water insoluble and water-soluble glucan synthesizing enzymes: GTF-S-I.

- Glucan synthesizing enzyme: GTF-I.

- Genes encoding the 3 forms are:

- GTF-C - GTF-S: GTF-I: GTF-B - GTF-SI: GTF-D [9].

Glucan Binding Protein (GBP): 3 distinct proteins with glucan binding activity are released: GBP-A, GBP-B and GBP-C.

Adhering of glucan to S. mutans becomes easy with these proteins. It makes the dental biofilm porous, thus contributing the nutrients for bacterial metabolism.
Dextranase, an enzyme of Dextran (major constituent of early dental plaque and prevents colonization of organism at early stage), removes it and thus bacteria can invade plaque at an early stage [10].

\section{Routes of Administration}

Two important routes of administrations through

Common Mucosal Immune Pathway are:-

1. Systemic route

2. Active gingiva-salivary route

Common Mucosal Immune System: This method is preferred for the induction of sectretory $\operatorname{IgA}$ antibodies. Following methods are used:

Oral Route: Relied on oral induction of immunity in the GALT. Oral feeding, gastric intubation, or in vaccine containing capsules or liposomes are best way of application for antigen.

Lehner $\mathrm{T}$. in his study showed that oral immunization with $\mathrm{S}$. mutans did not induce significant secretory $\operatorname{IgA}$ in monkeys depicting limited immunological memory in secretory $\operatorname{IgA}$ responses is and this may limit the value of oral immunization [11].

Intranasal Route: The NALT, nasal route administration procedure is preferred to induce immunity to bacterial antigens to avoid colonization and aggregation of microorganisms.

Katz $\mathrm{J}$ et al. inhis study showed that intranasal immunization of rats with $\mathrm{S}$. mutans antigen I/II combined with the B subunit of cholera toxin-induced a protective salivary immune response along with a reduction in $\mathrm{S}$. mutans accumulation and dental caries[12].

Minor Salivary Gland: Considered one of the best routes, takes less time and has broad ducts providing retrograde passage to bacteria and its products.

Tonsillar: A study showed that formalin-killed cells of S. sobrinus in rabbits by tonsillar administration reduced the carious sites in rabbits. Repeated application can induce $\operatorname{Ig} \mathrm{A}$ antibodies inbothmajor and minor salivary glands $[13,14]$.

Rectal: The lower intestinal tract has highest concentration of lymphoid follicles and thus it is known as inductive location for immune responses.

Systemic Route: IgG, IgM and IgA antibodies find their way into oral cavity via GCF and thus protect agains dental caries. However, Protection against caries was associated predominantly with increased serum IgG antibodies. 
Active gingiva-salivary route:In order to reduce side effects administration through GCF is considered as best route for immunity induction.Both $\operatorname{IgA}$ and $\operatorname{IgG}$ antibodies are induced through this method[10].

\section{Passive immunization}

1. Monoclonal antibodies: These antibodies to $\mathrm{S}$. mutans cell surface Ag I/II have been examined. Topical application where $\mathrm{S}$. mutans are more in number found to be more affected and showed massive reduction.

2. Bovine milk: Systemic immunization of cows with a vaccine using whole $S$. mutans has led to the bovine milk and whey- containing polyclonal $\mathrm{IgG}$ antibodies. This was then added to the diet of a rat model. The immune whey brought a drop in the caries level. [15]

3. Egg-yolk antibodies: Due to presence of formalin killed whole cells and cell associated GTFs reduction in caries was appreciated.

4. Transgenic plants: It is the first plant derived vaccine which is genetically modified. Being tasteless and colourless can be directly applied onto the teeth.

\section{Adjuvants \& delivery systems for dental caries vaccine}

Cholera toxin And E. Coli Heat-Labile Enterotoxin: Cholera toxin (CT) is used to provide mucosal immunity to a variety of bacterial and viral pathogens. Mucosal application of a soluble protein or peptide antigen alone rarely results in high or constant IgA responses. However, the addition of small amounts of $\mathrm{CT}$ or the closely related E.coli heat-labile enterotoxins (LT) can extensively enhance mucosal immune responses to intragastrically or intranasally applied mutans Streptococcal antigens or to peptides derived from these antigens. The coupling of the protein with the nontoxic unit of the cholera toxin was effective in suppressing the colonization of S. mutans [16].

Microcapsules and micro particles: Microcapsules and microparticles of polylactidecoglycolide (PLGA) used as local delivery systems. They have an ability to control the release rate, and degrade slowly without eliciting an inflammatory response to the polymer [16].

Fusing with salmonella: It act as effective vaccine vector when fusion done with various recombinant techniques.

Liposomes: Liposomes are bilayered phospholipids membrane vesicles manufactured to hold and deliver drugs and antigens. Administration of liposomes containing anti-idiotype (anti-id) vaccine provided partial protection against dental caries and also can bring about protective immune responses to pathogens of mucosal surfaces [17].

\section{Risk Associated with Caries Vaccine Usage}

Vaccination of human subjects against dental caries might increase their susceptibility to streptococcal endocarditis [18].

As per the research Streptococcal whole cells can induce heart reactive antibodies due to which the formulation of sub-unit vaccines for prevention and control of dental caries has been the crux for intense research [16].

\section{CONCLUSION}

It has been long since prevention of caries is a big concern and dental caries vaccine has been expected to work for caries prevention since as early as fifties of the $20^{\text {th }}$ century.

No caries vaccinations have been brought till now due to many reasons. One among them is its low ability to maintain protective antibody in oral fluids. Elimination of one of the commensal microorganisms is another challenge. Before introduction of anyvaccine in the market, one should have proper trials of these vaccines notdisturbing the microflora of oral cavity evolved since many centuries.

For a dental caries vaccine to be accepted by the dental profession, many questions need to be answered. One of the important questions is: what will be the long-term effect of vaccine action over the indigenous oral microflora? Also, can these vaccines inactivate the highest level of infection of caries caused by $\mathrm{S}$. mutans immunologically? Can the entry portals for S. mutans into the dental biofilm can be blocked with immunization? Can virulence factors associated with S. mutans induce an immune response? How safer these vaccines are compared to other preventive measures for dental caries? Will the professionals accept this vaccination mechanism as major prevention protocol for dental caries?

For future studies, two paths can be suggested. First, to search for new target virulence genes or antigenic proteins, develop vaccines, use the best combinations and administration technique and enhance further using nanotechnology. Second, existing bestproved animal trial vaccines can be improved to the required level.

\section{REFERENCES}

1. Clifford, M.S. (1995). The art and science of Operative Dentistry. $4^{\text {th }}$ ed. Mosby publications.

2. Lehner, T. (1992). Immunology of dental caries. Immunology of oral diseases. $3^{\text {rd }}$ ed. Blackwell Scientific publications.

3. Krithika, A.C., Kandaswamy, D., Gopikrishna, V.(2004). Caries vaccine-today's myth. J India Assoc Public Health Dent; 4:21-5. 
4. Mattos-Graner, R. O., \& Smith, D. J. (2004). The vaccination approach to control infections leading to dental caries. Brazilian Journal of Oral Sciences, 3(11), 595-608.

5. Gordon, N. (1985). Textbook on understanding dental caries Part II.1985; karger.

6. Park, K. (2004). Textbook of preventive and social medicine. $17^{\text {th }}$ ed. Bhanotidas publication.

7. Warren, L., Ernest, J. (2000). Medical microbiology and immunology. $6^{\text {th }}$ ed. Lange Medical Publishing Division.

8. Newman, N. (1988). Oral microbiology and immunology. W.B. Saunder's Company.

9. Iwaki, M., Okahashi, N., Takahashi, I., Kanamoto, T., Sugita-Konishi, Y., Aibara, K., \& Koga, T. (1990). Oral immunization with recombinant Streptococcus lactis carrying the Streptococcus mutans surface protein antigen gene. Infection and immunity, 58(9), 2929-2934.

10. Sharma, Y. (2018). "Dental Caries Vaccine - A Change". Acta Scientific Dental Sciences 2.10: 4144.

11. Lehner, T. (1992). Immunology of dental caries. Immunology of oral diseases.3ed. Blackwell scientific publications.

12. Katz, J. A. N. N. E. T., Harmon, C. C., Buckner, G. P., Richardson, G. J., Russell, M. W., \& Michalek, S. M. (1993). Protective salivary immunoglobulin A responses against Streptococcus mutans infection after intranasal immunization with $\mathrm{S}$. mutans antigen I/II coupled to the B subunit of cholera toxin. Infection and immunity, 61(5), 1964-1971.

13. Fukuizumi, T., Inoue, H., Tsujisawa, T., \& Uchiyama, C. (1999). Tonsillar Application of Formalin-Killed Cells ofStreptococcus sobrinus Reduces Experimental Dental Caries in Rabbits. Infection and immunity, 67(1), 426-428.

14. Smith, D. J. (2002). Dental caries vaccines: prospects and concerns. Critical Reviews in Oral Biology \& Medicine, 13(4), 335-349.

15. Michalek, S. M., Gregory, R. L., Harmon, C. C., Katz, J., Richardson, G. J., Hilton, T., ... \& McGhee, J. R. (1987). Protection of gnotobiotic rats against dental caries by passive immunization with bovine milk antibodies to Streptococcus mutans. Infection and immunity, 55(10), 23412347.

16. Shivakumar, K.M., Vidya, S.K., Chandu, G.N. (2009). Dental caries vaccine. Indian J Dent Res, 20(1), 2009.

17. Chen, L., Zhu, J., Li, Y., Lu, J., Gao, L., Xu, H., ... \& Yang, X. (2013). Enhanced nasal mucosal delivery and immunogenicity of anti-caries DNA vaccine through incorporation of anionic liposomes in chitosan/DNA complexes. PLoS One, 8(8).

18. Durack, D. T., Gilliland, B. C., \& Petersdorf, R. G. (1978). Effect of immunization on susceptibility to experimental Streptococcus mutans and Streptococcus sanguis endocarditis. Infection and immunity, 22(1), 52-56. 